\title{
Response of nitrite accumulation and microbial community to free ammonia and dissolved oxygen treatment of high ammonium wastewater
}

\author{
Qianwen Sui $^{1,2,3} \cdot$ Chong Liu ${ }^{1,2} \cdot J_{u n y a}$ Zhang $^{3} \cdot$ Hongmin Dong ${ }^{1,2} \cdot$ Zhiping Zhu $^{1,2}$ • \\ Yi Wang ${ }^{1,2}$
}

Received: 25 September 2015 / Revised: 11 November 2015 / Accepted: 14 November 2015 / Published online: 8 January 2016

(C) Springer-Verlag Berlin Heidelberg 2016

\begin{abstract}
The effects of free ammonia (FA) and dissolved oxygen (DO) on nitrite accumulation in the treatment of high ammonium wastewater and on the evolution of the microbial community were investigated. Under high DO conditions $(3.75 \pm 0.49 \mathrm{mg} / \mathrm{L}), \mathrm{FA}$ as high as $10.61 \pm 2.89 \mathrm{mg} \mathrm{NH} / \mathrm{L}$ maintained stable nitrite accumulation rate (NAR) of $84 \%$ with $\mathrm{NH}_{4}{ }^{+}-\mathrm{N}$ load of $2.05 \mathrm{~kg} \mathrm{~N} /\left(\mathrm{m}^{3}\right.$ day $)$ at sludge retention time (SRT) of 15-18 days. After 56 days of operation, Proteobacteria and Nitrosomonas were the dominant phylum and genus, respectively; Nitrosomonas increased from 21.14 to $54.57 \%$. By contrast, under relative low DO and low FA, nitrite-oxidizing bacteria (NOB) were nearly eliminated (NOB/AOB of 0 ; ammonium-oxidizing bacteria (AOB)), and NAR of $94 \%$ was achieved with lower $\mathrm{NH}_{4}{ }^{+}-\mathrm{N}$ load of $0.48 \mathrm{~kg} \mathrm{~N} /\left(\mathrm{m}^{3}\right.$ day $)$. DO correlated with AOB and NOB abundance, and FA decreased NOB activity and the NOB/AOB ratio. In conclusion, high FA and high DO conditions are optimal for efficient nitrite accumulation.
\end{abstract}

Electronic supplementary material The online version of this article (doi:10.1007/s00253-015-7183-z) contains supplementary material, which is available to authorized users.

Hongmin Dong

donghongmin@caas.cn

1 Institute of Environment and Sustainable Development in Agriculture, Chinese Academy of Agricultural Sciences, Beijing 100081, China

2 The Key Laboratory of Energy Conservation and Waste Treatment of Agricultural Structures, Ministry of Agriculture, Beijing 100081, China

3 Research Center for Eco-Environmental Sciences, Chinese Academy of Sciences, Beijing 100085, China
Keywords Nitrite accumulation $\cdot$ Free ammonia $\cdot$ Dissolved oxygen $\cdot$ Microbial community $\cdot$ High-throughput sequencing

\section{Introduction}

High ammonium $\left(\mathrm{NH}_{4}{ }^{+}-\mathrm{N}\right)$ wastewater (including animal production wastewater, landfill leachate, and anaerobic digestate of waste sludge) has harmful effects on bodies of water and aquatic plants without proper treatment, which has been widely studied with regard to biological nitrogen removal (BNR) (Zhang et al. 2007; Zhang et al. 2011; Guo et al. 2010). Shortcut nitrification and denitrification (SND) and anaerobic ammonium oxidation (Anammox) are two BNR processes suitable for the treatment of high ammonium wastewater. Highly efficient and stable nitrite accumulation is the first step (Peng and Zhu 2006; Wyffels et al. 2004)

The controlling parameters for nitrite accumulation include free ammonium (FA), free nitrous acid (FNA), dissolved oxygen (DO), SRT, and ammonium sludge load (Chuang et al. 2007; Chen et al. 2010; Vadivelu et al. 2007). Shortening SRT to 1-3.5 days could facilitate NOB washout (Regmi et al. 2014). DO level less than $1.0 \mathrm{mg} / \mathrm{L}$ is favorable for the inhibition of nitrite-oxidizing bacteria (NOB) (Kim et al. 2008), and de Graaff et al. (2010) indicated that DO of $1.5-1.7 \mathrm{mg} / \mathrm{L}$ was superior for nitrite accumulation in the treatment of high ammonium wastewater. Ruiz et al. (2003) reported that DO higher than $1.7 \mathrm{mg} / \mathrm{L}$ could not achieve nitrite accumulation. However, An et al. (2008) and Tokutomi et al. (2010) achieved approximately $90 \%$ NAR at DO of approximately $4 \mathrm{mg} / \mathrm{L}$ in the treatment of high ammonium wastewater. The mechanism of nitrite accumulation under high DO (approximately $4.0 \mathrm{mg} \mathrm{DO} / \mathrm{L}$ ) is unclear but is hypothesized to involve inhibition by FA. 
FA is one of the most important determinants of nitrite accumulation. However, the FA concentration range that inhibits NOB remains controversial. For instance, Anthonisen et al. (1976) reported that FA of $0.1-1.0 \mathrm{mg}-\mathrm{NH}_{3} / \mathrm{L}$ exerted an inhibitory effect on NOB. Recent research revealed that to maintain efficient nitrification accumulation FA up to 10 $15 \mathrm{mg} \mathrm{NH}_{3} / \mathrm{L}$ is required (Chen et al. 2010; Park et al. 2014).

The evolution of microbial community in response to FA and DO treatment can help reveal the microbial mechanism of effects of the controlling parameters on ammonium oxidation and nitrite accumulation. High-throughput sequencing technology has been used to evaluate the changes in the microbial community in wastewater treatment systems (Ma et al. 2013) and generate thousands of operational taxonomic units (OTUs) that provide insight into the shift of the microbial community (Yadav et al. 2014). In the nitrite accumulation process, the evolution of functional bacteria involves maintaining the growth of $\mathrm{AOB}$ and inhibiting the growth of NOB. However, ammonium oxidization is the rate-limiting step in the BNR process (Otawa et al. 2006). The controlling parameters of nitrite accumulation greatly impact the efficiency of ammonium oxidation. Ciudad et al. (2007) reported that the ammonia oxidation rate is linearly correlated with DO in the $0.6-5.0-\mathrm{mg} / \mathrm{L}$ range. Decreasing the DO concentration can enable nitrite accumulation but also reduces the activity of AOB (Park et al. 2014). Chen et al. (2010) proposed that FA of $10-20 \mathrm{mg} \mathrm{NH}_{3} / \mathrm{L}$ was superior for the enrichment of $\mathrm{AOB}$ and elimination of NOB. To achieve a high efficiency of ammonium oxidation and nitrite accumulation, the effect of different controlling parameters, including low DO and high FA, on ammonium oxidation and nitrite accumulation and the evolution of the microbial community should be compared.

Thus, in this study, to evaluate the different combined effect of DO and FA on shortcut nitrification, three identical reactors fed synthetic wastewater with a high $\mathrm{NH}_{4}{ }^{+} \mathrm{-N}$ concentration of approximately $1000 \mathrm{mg} / \mathrm{L}$ were established. The DO of 1.7 and 3.5 was defined as relatively low and high DO treatment, and FA of 1.0 and $10 \mathrm{mg} / \mathrm{L}$ was defined as relatively low and high FA treatment. The aims of this study were (1) to investigate the nitrite accumulation mechanism under relatively high DO conditions and (2) to compare the performance of different FA and DO combined treatments and explore the microbial mechanism to identify more efficient control parameters.

\section{Materials and methods}

\section{Setup and operation of the reactors}

The experiment was conducted in a continuous activated sludge system consisting of an aeration reactor with a working volume of $10 \mathrm{~L}$ and followed by a $10-\mathrm{L}$ settler.
A microporous aerator was placed at the bottom of the reactor. There was $100 \%$ return sludge flow between the settler and the reactor. The temperature was controlled at $25 \pm 0.5{ }^{\circ} \mathrm{C}$. Three sets of identical systems were assembled, reactors $\mathrm{A}, \mathrm{B}$, and $\mathrm{C}$. The reactors were fed synthetic wastewater with $\mathrm{NH}_{4}{ }^{+}-\mathrm{N}$ concentration of $1000 \mathrm{mg} / \mathrm{L}$ containing $\mathrm{NH}_{4} \mathrm{HCO}_{3}(5.64 \mathrm{~g} / \mathrm{L})$, $\mathrm{KH}_{2} \mathrm{PO}_{4}(0.025 \mathrm{~g} / \mathrm{L}), \mathrm{MgSO}_{4} \cdot 7 \mathrm{H}_{2} \mathrm{O}(0.3 \mathrm{~g} / \mathrm{L}), \mathrm{CaCl}_{2}$. $2 \mathrm{H}_{2} \mathrm{O}(0.14 \mathrm{~g} / \mathrm{L})$, and $5 \mathrm{~mL} / \mathrm{L}$ trace element solution consisting of $\mathrm{Na}_{2}$-EDTA $(50 \mathrm{~g} / \mathrm{L}), \mathrm{FeSO}_{4} \cdot 7 \mathrm{H}_{2} \mathrm{O}(5.0 \mathrm{~g} /$ $\mathrm{L}), \mathrm{CuSO}_{4} \cdot 5 \mathrm{H}_{2} \mathrm{O}(1.57 \mathrm{mg} / \mathrm{L}), \mathrm{MnCl}_{2} \cdot 4 \mathrm{H}_{2} \mathrm{O}(5.06 \mathrm{~g} / \mathrm{L})$, $\mathrm{ZnSO}_{4} \cdot 7 \mathrm{H}_{2} \mathrm{O}(5.0 \mathrm{~g} / \mathrm{L}), \mathrm{CoSO}_{4} \cdot 5 \mathrm{H}_{2} \mathrm{O}(1.9 \mathrm{~g} / \mathrm{L})$, and $\mathrm{NaMoO}_{4} \cdot 2 \mathrm{H}_{2} \mathrm{O}(1.1 \mathrm{~g} / \mathrm{L}) . \mathrm{NaHCO}_{3}(6.0 \mathrm{~g} / \mathrm{L})$ was added as needed as a pH buffer and the sole carbon source. The seed sludge with a total volume of $24 \mathrm{~L}$ and MLVSS of $8.6 \mathrm{~g} / \mathrm{L}$ was carried from a municipal wastewater plant after settlement distributed evenly to the three reactors.

Reactor A was maintained under relatively high FA and high DO conditions (FA of $10 \mathrm{mg} / \mathrm{L}$ and DO of 3$4 \mathrm{mg} / \mathrm{L}$ ), reactor $\mathrm{B}$ was maintained under relatively high FA and low DO conditions (FA higher than $10 \mathrm{mg} / \mathrm{L}$ and DO of $1.5-2.0 \mathrm{mg} / \mathrm{L}$ ), and reactor $\mathrm{C}$ was maintained at relatively low FA and low DO conditions (FA of $1 \mathrm{mg} / \mathrm{L}$ and DO of $1.5-2.0 \mathrm{mg} / \mathrm{L}$ ).

The inoculation phase was 4 weeks, and the reactors were operated with continuous flow. The influent concentration was stepped up, and the FA and DO conditions of the three reactors were maintained as described above. The operating parameters during the inoculation phase are shown in Fig. S1. After the inoculation phase, the MLSS concentrations of reactors A, B, and C were $5.10,4.36$, and $4.38 \mathrm{~g} / \mathrm{L}$, and the MLVSS concentrations were $3.86,3.23$, and $3.29 \mathrm{~g} / \mathrm{L}$, respectively. Sludge was periodically discharged from the settler to maintain the SRT of 15-18 days. To prevent discharge of nitrite wastewater, the effluent of the reactors were collected and advanced treated by another treatment device to reach discharge standard (not shown).

Free ammonium (FA) was calculated according to Eq. (1), developed by Anthonisen et al. (1976):

$\mathrm{FA}=\frac{17}{14} \times \frac{\left(\left[\mathrm{NH}_{3}-\mathrm{N}\right]+\left[\mathrm{NH}_{4}-\mathrm{N}\right]_{]_{\text {zzone }}} \times 10^{\mathrm{pH}}\right)}{\begin{array}{l}6344 \\ \mathrm{e} 273+\mathrm{t}+10^{\mathrm{pH}}\end{array}}$

where FA is the free ammonium concentration $\left(\mathrm{mg} \mathrm{NH}_{3} / \mathrm{L}\right)$; $\left(\left[\mathrm{NH}_{3}-\mathrm{N}\right]+\left[\mathrm{NH}_{4}{ }^{+}-\mathrm{N}\right]\right)_{\mathrm{O}}$ zone is the total ammonium nitrogen in the reactor $(\mathrm{mg} / \mathrm{L})$; $\mathrm{t}$ is the water temperature in the $\mathrm{O}$ zone $\left({ }^{\circ} \mathrm{C}\right)$; and $\mathrm{pH}$ is the $\mathrm{pH}$ value.

$\mathrm{AOR}=\frac{\left[\mathrm{NH}_{4}-\mathrm{N}\right]_{\text {inf }}-\left[\mathrm{NH}_{4}-\mathrm{N}\right]_{\text {eff }}}{\left[\mathrm{NH}_{4}-\mathrm{N}\right]_{\text {inf }}}$ 
where AOR is the ammonium oxidation rate $(\%) ;\left(\mathrm{NH}_{4}{ }^{+}-\mathrm{N}\right)_{\text {inf }}$ is the influent ammonium nitrogen concentration $(\mathrm{mg} / \mathrm{L})$; and $\left(\mathrm{NH}_{4}{ }^{+}-\mathrm{N}\right)_{\text {eff }}$ is the effluent ammonium nitrogen concentration $(\mathrm{mg} / \mathrm{L})$.

$\mathrm{NAR}=\frac{\left[\mathrm{NO}_{2}-\mathrm{N}\right]_{\text {eff }}}{\left[\mathrm{NO}_{2}-\mathrm{N}\right]_{\mathrm{eff}}+\left[\mathrm{NO}_{3}-\mathrm{N}\right]_{\text {eff }}}$

where NAR is the nitrite accumulation rate $(\%) ;\left(\mathrm{NO}_{2}{ }^{-}-\mathrm{N}\right)_{\mathrm{eff}}$ is the effluent nitrite nitrogen concentration $(\mathrm{mg} / \mathrm{L})$; and $\left(\mathrm{NO}_{3}{ }^{-}\right.$$\mathrm{N})_{\text {eff }}$ is the effluent nitrate nitrogen concentration $(\mathrm{mg} / \mathrm{L})$.

\section{Nitrification batch test}

Nitrification experiment was performed to determine the AOB and NOB activities in the reactors. Mixed liquor samples were taken from the reactors each week to determine the AOB and NOB activities according to the method of Wang et al. (2013).

\section{Sampling}

Activated sludge samples were collected from the reactors at days 15,37 , and 50 of the running period and were named A1, $\mathrm{A} 2$, and $\mathrm{A} 3$ for reactor $\mathrm{A} ; \mathrm{B} 1, \mathrm{~B} 2$, and $\mathrm{B} 3$ for reactor $\mathrm{B}$; and $\mathrm{C} 1, \mathrm{C} 2$, and $\mathrm{C} 3$ for reactor $\mathrm{C}$, respectively. The seed sludge was named S0. The ten sludge samples were stored in $-70{ }^{\circ} \mathrm{C}$ freezer for microbial analysis. Influent and effluent samples were collected every day for chemical analysis.

\section{Chemical analyses}

$\mathrm{pH}$ and DO were measured on-site using a handheld analyzer (HACH Sension378, HACH Company, USA). $\mathrm{NH}_{4}{ }^{+}-\mathrm{N}$ was measured using the distillation method (B-324, BüCHI, Switzerland); $\mathrm{NO}_{2}{ }^{-}-\mathrm{N}$ and $\mathrm{NO}_{3}{ }^{-} \mathrm{N}$ were measured using a flow injection analyzer (FIAstar 5000, FOSS, Denmark). The chemical analysis results are presented as the mean \pm standard deviation (SD).

\section{DNA extraction and PCR amplification}

Genomic DNA was extracted from $0.5 \mathrm{~mL}$ of each mixed liquid sample using the QiaAmp DNA kit (QiaGen, Germany) according to the manufacturer's protocol. The purity and concentration of the extracted genomic DNA were evaluated using a SmartSpec Plus (Bio-Rad, USA) at 260/ $280 \mathrm{~nm}$, and the integrity of the genomic DNA was verified by gel electrophoresis in $1 \%$ agarose gels. The V4 region of the bacterial $16 \mathrm{~S}$ ribosomal RNA gene was amplified by PCR $\left(95{ }^{\circ} \mathrm{C}\right.$ for $2 \mathrm{~min}$, followed by 25 cycles of $95{ }^{\circ} \mathrm{C}$ for $30 \mathrm{~s}$, $55^{\circ} \mathrm{C}$ for $30 \mathrm{~s}$, and $72{ }^{\circ} \mathrm{C}$ for $30 \mathrm{~s}$ and a final extension at $72{ }^{\circ} \mathrm{C}$ for $\left.5 \mathrm{~min}\right)$ using the primers $515 \mathrm{~F}\left(5^{\prime}\right.$-barcodeGTGCCAGCMGCCGCGG-3') and $907 \mathrm{R}^{\prime}$ ( $5^{\prime}$ -
CCGTCAATTCMTTTRAGTTT-3'). Barcode is an eightbase sequence unique to each sample. PCR reactions were performed in triplicate in $20 \mu \mathrm{L}$ containing $4 \mu \mathrm{L}$ of $5 \times$ FastPfu Buffer, $2 \mu \mathrm{L}$ of $2.5 \mathrm{mM}$ dNTPs, $0.8 \mu \mathrm{L}$ of each primer $(5 \mu \mathrm{M}), 0.4 \mu \mathrm{L}$ of FastPfu Polymerase, and $10 \mathrm{ng}$ of template DNA.

\section{Illumina MiSeq sequencing, sequence processing, and bioinformatics analysis}

Amplicons were extracted from $2 \%$ agarose gels and purified using the AxyPrep DNA Gel Extraction Kit (Axygen, USA) according to the manufacturer's instructions and quantified using QuantiFluor ${ }^{\mathrm{TM}}$-ST (Promega, USA). Purified amplicons were pooled in equimolar and paired-end sequenced $(2 \times 250)$ on an Illumina MiSeq platform (Illumina, USA) according to the standard protocols of Majorbio Bio-Pharm Technology Co., Ltd., Shanghai, China.

Depending on the unique 8-bp barcode, sequencing reads were assigned to each sample, and the barcode was then removed. Mothur was used for sequence quality control as described by Kozich et al. (2013). Briefly, the sequence data were first subjected to stringent quality control including (1) pyronoise/flowgram noise reduction; (2) removal of all sequences shorter than $375 \mathrm{bp}$ and more than $400 \mathrm{bp}$; (3) sequences with more than one mismatch in the barcode region, two mismatches in the primer sequence, zero ambiguous bases, or eight homopolymers. The remaining sequences were aligned using the SILVA bacterial database, and the screening of sequences was optimized using the parameters optimize $=$ start and criteria $=90$. Potential sequencing errors were removed by implementing a pseudo-single linkage algorithm integrated into mothur, which clustered sequences with single-base differences into the same sequence. Chimeric sequences were detected and removed using the chimera.slayer command with the sequence collection in this study as the database. The database was further classified to remove sequences similar to chloroplast or cyanobacteria, and 361,507 clean reads from ten samples were finally obtained, with a range of 30,816 to 43,295 reads for each sample. All clean reads were deposited in MG-RAST (http://metagenomics.anl. gov/linkin.cgi?project=13440).

The taxonomic classification of the sequences in each sample was conducted individually using the Ribosomal Database Project (RDP) Classifier as previously suggested (Zhang et al. 2015). The sequences were assigned to different taxonomy levels at the bootstrap cutoff of $50 \%$ suggested by the RDP (Wang et al. 2007). In addition, the sequences in each set were assigned to phylotype clusters at cutoff levels of 3 and $6 \%$, also as described previously (Zhang et al. 2012), and on the basis of these clusters, rarefaction curves, $\mathrm{H}^{\prime}, \mathrm{E}$, varH, and Chaol richness indices were calculated using the relevant RDP pipeline modules. Venn diagrams were plotted using 
mothur 1.35 based on the species level with a sequence similarity threshold of $97 \%$.

\section{Statistical analysis}

Statistical calculations and data analysis were performed using the SPSS 20 statistical software package (IBM, USA). The values are presented as the mean \pm standard deviation. Spearman rank correlations were used to assess the association between operating variables and microbial parameters, together with biochemical parameters. The Circos graph was built using Circos software (Krzywinski et al. 2009). Heatmapping of the top ten genera in each sample was conducted using R packages. Principal component analysis (PCA) and redundancy analysis (RDA) were performed using Canoco 5.0 (Microcomputer Power, USA).

\section{Results}

\section{Nitrite accumulation with the three treatments}

\section{Nitrite accumulation under high FA and high DO}

The DO and FA concentrations of the three treatments are shown in Fig. 1a, b. The influent $\mathrm{NH}_{4}{ }^{+}-\mathrm{N}$ and effluent $\mathrm{NH}_{4}{ }^{+}-\mathrm{N}, \mathrm{NO}_{2}{ }^{-}-\mathrm{N}, \mathrm{NO}_{3}{ }^{-}-\mathrm{N}$ are shown in Fig. 1c and Table 1. Relatively high FA and DO were maintained in reactor A. Nitrite accumulation occurred rapidly during the initial 10 days, with HRT of 2.0 days and volumetric loading rate of $0.44 \pm 0.10 \mathrm{~kg} \mathrm{~N} /\left(\mathrm{m}^{3}\right.$ day $)$. The AOR and NAR reached greater than $95 \%$ at FA and DO values averaging 7.14 and $4.22 \mathrm{mg} / \mathrm{L}$, respectively. However, the nitrite accumulation was unstable. From day 15 to 30 , due to the rapid removal of ammonium, the FA concentration decreased to $4.05 \mathrm{mgNH}_{3} / \mathrm{L}$ and the nitrite accumulation gradually disappeared.

After day 15, to increase the FA level in the reactor, HRT decreased from 2 to 0.5 days (Fig. 1c), and the $\mathrm{NH}_{4}{ }^{+}-\mathrm{N}$ volumetric load increased to $2.05 \pm 0.16 \mathrm{~kg} \mathrm{~N} /\left(\mathrm{m}^{3}\right.$ day) (sludge load of $1.28 \mathrm{~kg} \mathrm{~N} /(\mathrm{kg}$ MLVSS day)). From day 34 to 56, FA increased and fluctuated between 7 and $16 \mathrm{mg} \mathrm{NH}_{3} / \mathrm{L}$ (with an average of $10.61 \pm 2.89 \mathrm{mg} \mathrm{NH}_{3} / \mathrm{L}$ ) at $3.75 \pm 0.49 \mathrm{mg} / \mathrm{L} \mathrm{DO}$, and AOR and NAR reached 91 and $84 \%$, respectively.

The AOB activity (Table 1) was 3.41-fold higher between day 34 and 56 compared to day 1 to 15 , indicating enhancement by the high DO treatment. The NOB activity was inhibited by the high FA treatment from day 34 to 56, when NOB activity was 3.56-fold lower than that of day 1 to 15 . However, no inhibitory effect of FA on AOB activity was observed. Thus, high FA and high DO resulted in higher

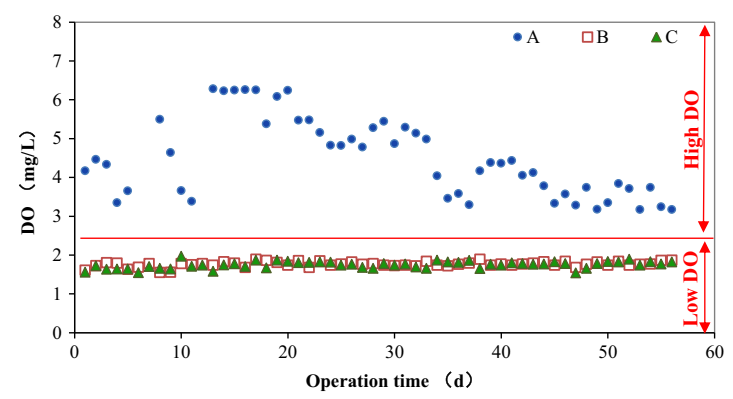

(A)

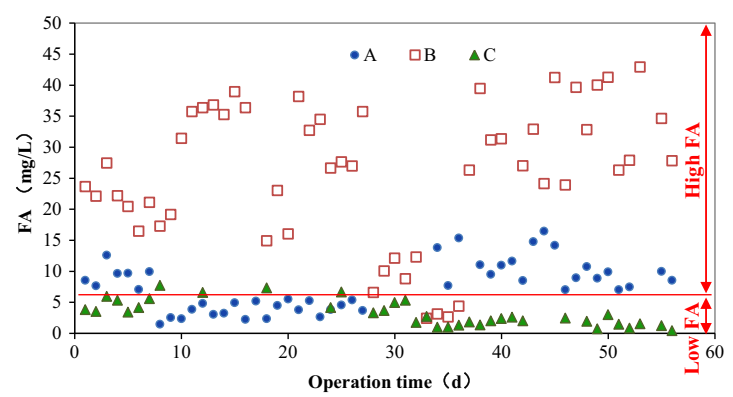

(B)

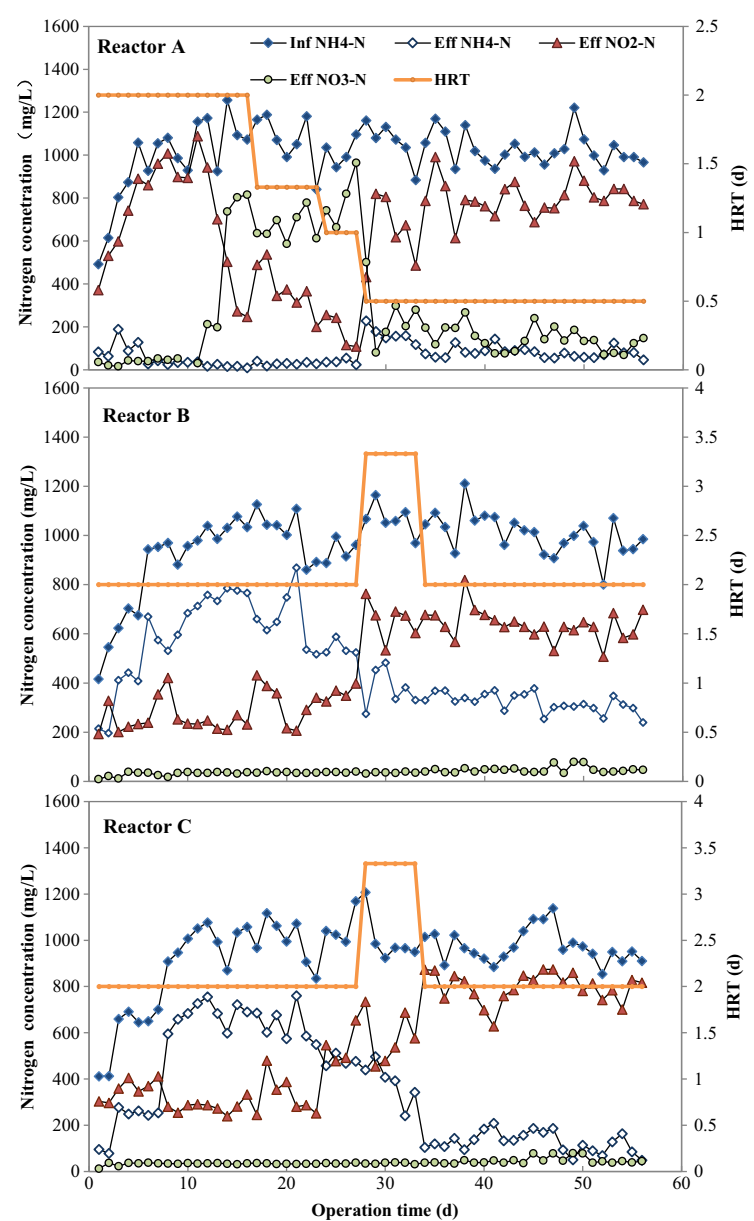

(C)

Fig. 1 The DO (a) and FA (b) concentrations, and influent and effluent nitrogen concentrations and HRTs of the three reactors (c) 


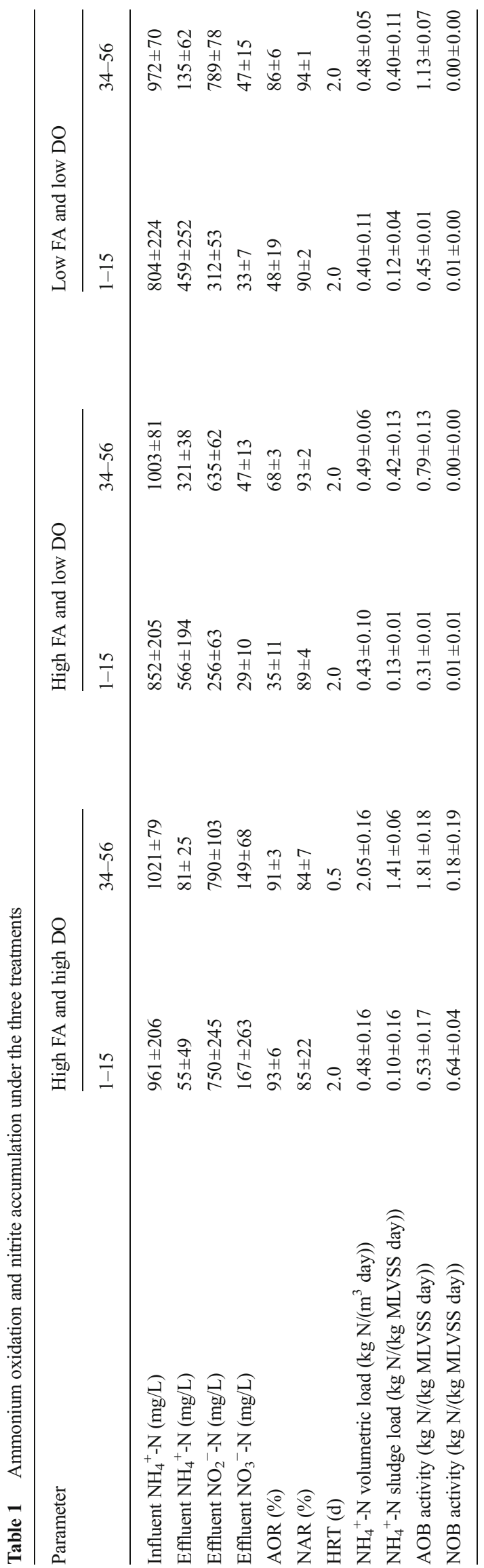

AOB activity than NOB activity, which facilitated nitrite accumulation.

\section{Nitrite accumulation under low FA and low DO}

Ammonium oxidation and nitrite accumulation under low FA and low DO in reactor $\mathrm{C}$ are illustrated in Fig. 1c. Park et al. (2014)) and de Graaff et al. (2010) indicated that $1.5-2.5 \mathrm{mg} / \mathrm{L}$ DO is beneficial for partial nitrification, whereas an excessively lower DO concentration $(\leq 0.5 \mathrm{mg} / \mathrm{L})$ may reduce the nitrification rate. The DO concentration was maintained at $1.75 \pm$ $0.09 \mathrm{mg} / \mathrm{L}$ throughout the running period. During the first 15 days, AOR was $48 \pm 19 \%$. Although the $\mathrm{pH}$ was $7.31 \pm$ 0.14 , for the treatment of high ammonium wastewater, the residual ammonium contributed to a relatively high FA of $5.54 \pm 1.74 \mathrm{mg} \mathrm{NH} / \mathrm{L}$, which may inhibit AOB activity. In addition, low DO is another inhibitory factor for $\mathrm{AOB}$ activity.

FA was related to $\mathrm{NH}_{4}{ }^{+}-\mathrm{N}$ load and was easily formed even at neutral $\mathrm{pH}$ if the $\mathrm{NH}_{4}{ }^{+}-\mathrm{N}$ load was too high. To decrease FA and enhance AOR in the reactor, from day 28 to 33, HRT was regulated from 2.0 to 3.33 days, and the $\mathrm{NH}_{4}{ }^{+} \mathrm{N}$ load was decreased to $0.3 \mathrm{~kg} \mathrm{~N} /\left(\mathrm{m}^{3}\right.$ days). The $\mathrm{NH}_{4}{ }^{+}-\mathrm{N}$ oxidation time was extended. After the recovery of HRT to 2.0 at day 33, AOR was increased to $86 \%$, and NAR was maintained at $94 \%$ at $\mathrm{FA}$ of $1.67 \pm 0.73 \mathrm{mg} \mathrm{NH} / \mathrm{L}$ and $\mathrm{DO}$ of $1.77 \pm$ $0.08 \mathrm{mg} / \mathrm{L}$.

After 56 days of operation, under the low DO and low FA condition, $\mathrm{AOB}$ activity was enhanced by 2.5 -fold compared to the initial 15 days (Table 1). NOB activity was not detected, implying that NOB elimination was possible under the relatively low DO treatment. From day 34 to 56, the AOB activity and the NOB activity in reactor $\mathrm{C}$ were both lower than in reactor $\mathrm{A}$. Thus, low DO levels may inhibit both $\mathrm{AOB}$ and NOB more strongly than FA.

\section{Nitrite accumulation under high FA and low DO}

To test the co-inhibition effect of FA and DO, high FA and low $\mathrm{DO}$ conditions were maintained in reactor $\mathrm{B}$. The ammonium oxidization and nitrite accumulation performance are presented in Fig. 1c. To simulate high FA conditions, the $\mathrm{pH}$ was maintained at 7.5-8.0 higher than in the low FA treatment in reactor $\mathrm{C}$ ( $\mathrm{pH}$ of 7.3 ), whereas $\mathrm{DO}$ was $1.5-2.0 \mathrm{mg} / \mathrm{L}$, similar to the value in reactor $\mathrm{C}$. Under the dual inhibitory effects of FA and DO, during the initial 28-day period, only $40 \%$ of ammonium was oxidized. From day 28 to 33, HRT was regulated as in the treatment using low FA and low DO in reactor C. After recovery of the HRT, AOR increased to $68 \%$, lower than the performance in reactor $\mathrm{C}$. With more residual $\mathrm{NH}_{4}{ }^{+}-$ $\mathrm{N}$ in the reactor and a relatively high $\mathrm{pH}$, the mean $\mathrm{FA}$ was $32.81 \pm 6.89 \mathrm{mg} \mathrm{NH}_{3} / \mathrm{L}$ from day 34 to 56 , higher than under the high FA and DO conditions in reactor A. Under low DO $(1.78 \pm 0.05 \mathrm{mg} / \mathrm{L})$ and high FA conditions, ammonium 
oxidization was inhibited and could not be enhanced despite the moderation of the HRT and the $\mathrm{NH}_{4}{ }^{+} \mathrm{N}$ load. For the treatment of high ammonium wastewater, FA was easily formed in the low DO environment. Although the AOB activity increased during the running period, it was the lowest among the three treatments from day 34 to 56 . NOB activity was not detected. This result indicates that high FA and low DO co-inhibited both AOB and NOB activities and are not desirable for the oxidization of high ammonium wastewater.

\section{Miseq sequencing and analysis}

\section{Changes in microbial community diversity}

Sequencing of the V4 region of the 16S rDNA gene in water samples yielded a total of 361,507 valid reads of $392 \mathrm{bp}$, and 5190 OTUs were identified at the $97 \%$ sequence similarity level. The observed OTUs and richness indexes of Chaol, $\mathrm{H}^{\prime}$, $\mathrm{E}$, and varH are presented in Table S1. The identified OTUs were more abundant in the seed sludge carried from the municipal wastewater plant, indicating relatively higher bacterial diversity. However, as the reactors ran over time, the OTUs were observed to gradually decline in each treatment group. Richness indexes also differed among the samples. Representative rarefaction curves were plotted for the activated sludge samples to determine whether the sampling was complete for the microbial communities and revealed relatively full samplings with curves approaching the asymptote during ammonium oxidation. The rarefaction curves in this study (Fig. S2) indicated an adequate species detection rate in the sludge samples. Moreover, the richness indexes and rarefaction curves indicated a selective effect of environmental factors on bacterial diversity that facilitated the formation of specific and functional microbiota, particularly in A3, which had the lowest richness indexes.

\section{Comparison of bacterial communities among samples}

All sequences were classified into 34 phyla or groups by the RDP classifier at $50 \%$. The predominant bacterial components of samples from different treatments were similar (Fig. 2; Table S2). Proteobacteria, Bacteroidetes, Plactomycetes, Chloroflexi, and Firmicutes were the five most dominant phyla in the activated sludge samples. Ma et al. (2013) reported that Proteobacteria and Bacteroidetes are the predominant phyla in activated sludge systems. Proteobacteria were present in the highest percentage among the three treatments and increased from $48.28 \%$ (A1) to $66.53 \%$ (A3) under high FA and high DO conditions and from $40.46 \%(\mathrm{C} 1)$ to $48.27 \%(\mathrm{C} 3)$ under low $\mathrm{DO}$ and low FA conditions but decreased from $39.31 \%$ (B1) to $31.62 \%$ (B3) under high FA and low DO conditions. Bacteroidetes was the second most dominant phylum in the three reactors, with an abundance of $27.05 \%$ in $\mathrm{A} 3,44.41 \%$ in $\mathrm{B} 3$, and $32.64 \%$ in C3 at day 50.

With the continuous operation of the three reactors, different AOR and NAR values were observed (Fig. 1c) and the microbiota gradually adapted to the treatment conditions. A species-based Venn diagram (Fig. S3) revealed that the number of OTUs shared by the three treatments gradually decreased from 634 OTUs $(26.29 \%)$ at day 15 to 369 OTUs $(19.84 \%)$ at day 37 and 285 OTUs $(17.37 \%)$ at day 50 (Fig. S3A). The number of shared OTUs in the same reactor among the three sampling times also differed, with 349 OTUs $(17.30 \%)$ in reactor A, 494 OTUs $(23.78 \%)$ in reactor B, and 447 OTUs $(23.28 \%)$ in reactor C (Fig. S3B).

The ten most abundant genera in each sample (Fig. 3; Table S3) were selected to analyze the microbial community structure. The composition of bacteria at the genus level in the seed sludge sample (S0) was relatively evenly distributed compared with the samples obtained from the three reactors. The dominant genera in the S0 sample were Lewinella (5.18\%), Ignavibacterium (3.12\%), Thauera (3.04\%), and Longilinea (3.01\%). The bacterial compositions of the samples in the different treatments changed over time and gradually diverged greatly. Under high FA and high DO conditions, the proportions of Nitrosomonas, Gemmatimonas, and Pedobacter gradually increased. Nitrosomonas was the most common AOB in the activated sludge system (Persson et al. 2014; Waheed et al. 2013) but represented only $0.42 \%$ of the S0 sample, indicating a dramatic increase. The proportion of Nitrosomonas increased from $21.14 \%$ in $\mathrm{A} 1$ to $54.57 \%$ in A3, far higher than in B3 (16.00\%) and C3 (22.61\%). This result indicates that high FA and high DO promoted the proliferation of $\mathrm{AOB}$, which could explain the higher $\mathrm{NH}_{4}{ }^{+}-\mathrm{N}$ load and AOB activity (Table 1) than that of the other two treatments. Under high FA and low DO conditions, Gulbenkiania, Moheibacter, Haliscomenobacter, and Leadbetterella gradually increased. Under low FA and low DO conditions, the genera of Comamonas, Paludibacter, Brumimicrobium, Moheibacter, and Hydrotalea gradually proliferated. The increases in certain genera reflect their gradual emergence and adaptation under the environmental conditions of the different FA and DO treatments.

$\mathrm{NH}_{4}{ }^{+}-\mathrm{N}$ and $\mathrm{NO}_{2}{ }^{-}-\mathrm{N}$ oxidation are performed by AOB (Nitrosomonas) and NOB (Nitrobacter, Nitrospira), respectively (Persson et al., 2014; Waheed et al., 2013). The relative abundance of NOB and AOB differed greatly with different treatments, as shown in Table 2. Nitrospira was the dominant NOB in S0, outcompeting Nitrobacter in the seed sludge from the municipal wastewater treatment plant. The NOB/AOB (Nitrobacter/Nitrosomonas and Nitrospira/Nitrosomonas) ratio was $273.6 \%$, reflecting the complete nitrification system. 


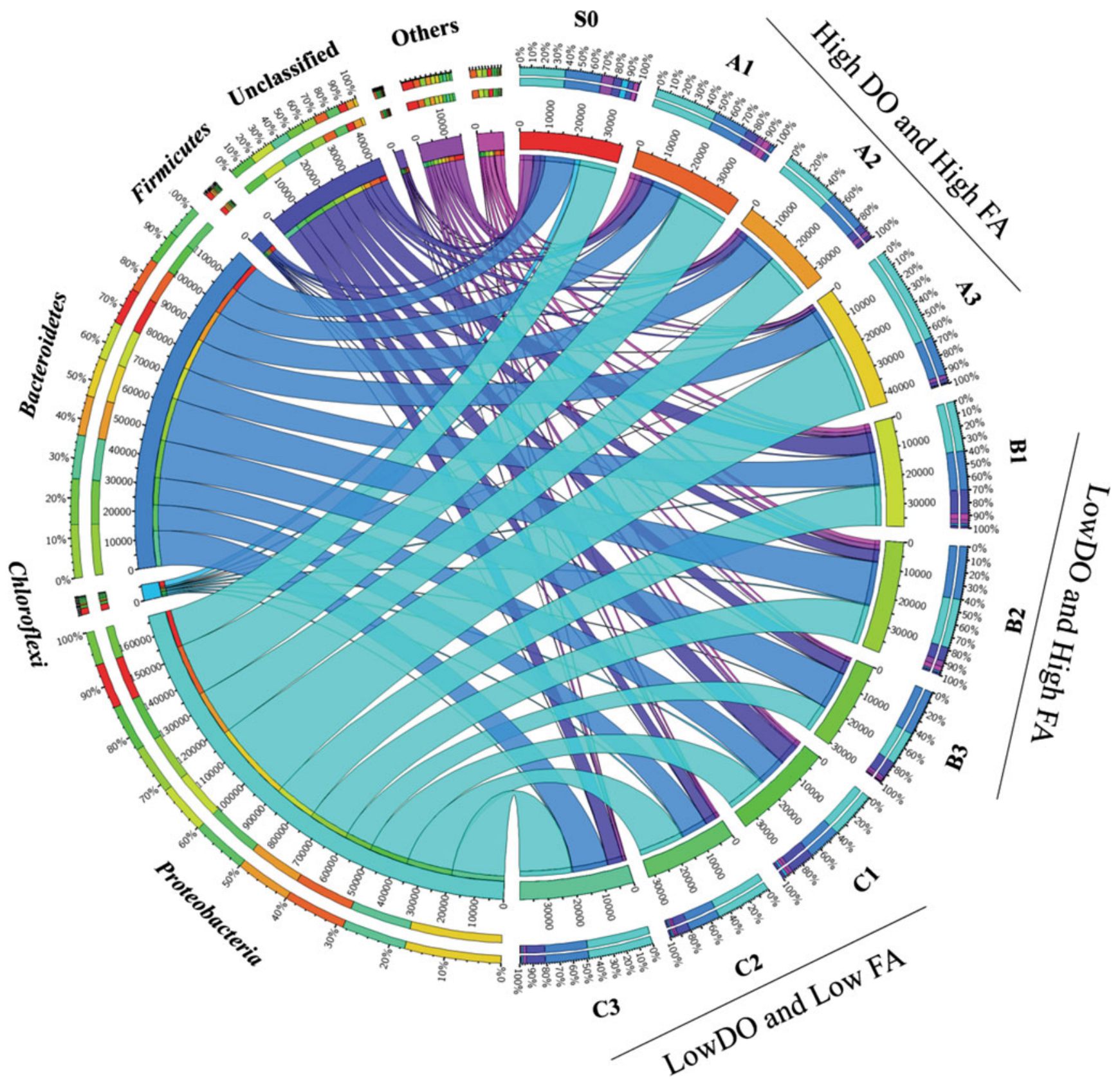

Fig. 2 Distribution of microbial community for each sample at phylum level. The data were visualized by Circos (Krzywinski et al. 2009). The width of the bars from each phylum indicate the relative abundance of that phylum in the sample

In all three reactors, the ratios of Nitrobacter/Nitrosomonas and Nitrospira/Nitrosomonas decreased during the running period. In the high FA and high DO treatment, Nitrobacter seemed to play a more important role than Nitrospira, with a higher proportion of $\mathrm{AOB}$. With decreasing $\mathrm{NOB} / \mathrm{AOB}$, Nitrospira/Nitrosomonas declined to 0 and Nitrobacter/ Nitrosomonas was $1.1 \%$ at day 50 . By contrast, with the other two treatments, the ratios of both Nitrobacter/Nitrosomonas and Nitrospira/Nitrosomonas were 0 at day 50. NOB was eliminated in reactors $\mathrm{B}$ and $\mathrm{C}$, in which $\mathrm{DO}$ was low.

\section{The relationship between bacterial community and operational parameters}

Principal component analysis (PCA) and redundancy analysis (RDA) were performed to reveal the distributions of samples and species along environmental factor gradients at the genus level (Fig. 4). In the different DO and FA treatments, the microbial communities of $\mathrm{A} 2, \mathrm{~A} 3$ and $\mathrm{C} 2, \mathrm{C} 3$ cluster separately, whereas $\mathrm{B} 2$ and $\mathrm{B} 3$, which featured $\mathrm{FA}$ and $\mathrm{DO}$ coinhibition, were distributed between the two clusters. These 


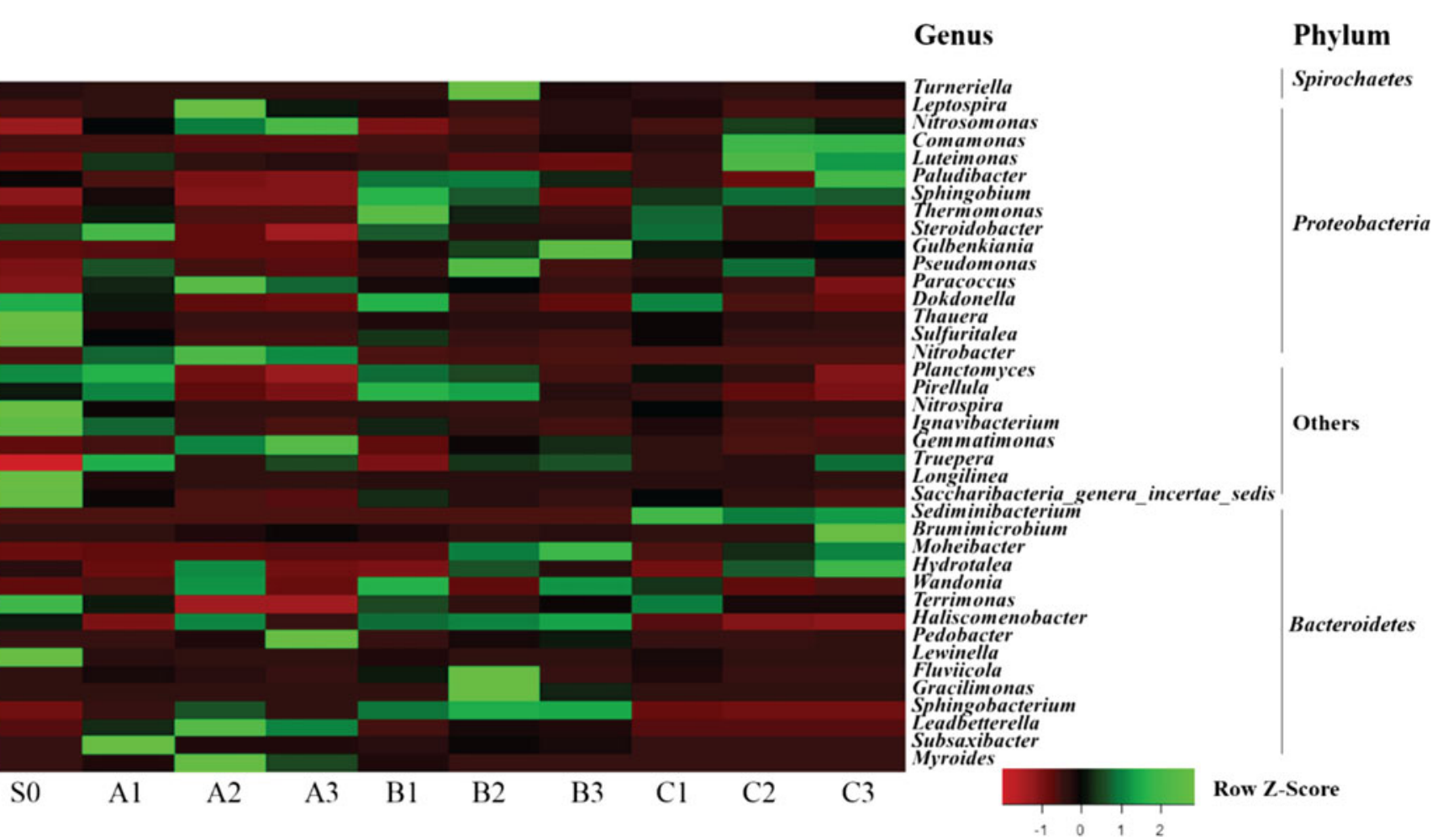

Fig. 3 Heatmap or the top ten genera in each sample built by R. The top ten genera in each sample were selected (a total of 40 genera for all ten samples) and compared with their abundances in other samples by row z-score

results revealed the shifts in microbial community structure in response to the FA and DO treatments.

RDA was applied to explain the possible correlation between bacterial community and operational and environmental parameters. As shown in Fig. 4, the parameters $\mathrm{FA}, \mathrm{pH}$, and DO had important effects on the microbial community structure. The $\mathrm{pH}$ enhanced ammonium nitrogen transfer to FA and increased the FA level in the reactor. The microbial communities of A2 and

Table 2 The ratio of NOB to Nitrosomonas

\begin{tabular}{llll}
\hline \multirow{2}{*}{ Treatment } & Sample number & \multicolumn{2}{l}{ Ratio to Nitrosomonas (\%) } \\
\cline { 3 - 4 } & & Nitrobacter & Nitrospira \\
\hline Seed sludge & S0 & 0.6 & 273 \\
High FA and high DO & A1 & 2.2 & 0.6 \\
& A2 & 2.6 & 0.0 \\
High FA and low DO & A3 & 1.1 & 0.0 \\
& B2 & 0.0 & 0.5 \\
& B3 & 0.0 & 0.0 \\
Low FA and low DO & C1 & 0.0 & 0.0 \\
& C2 & 0.0 & 1.3 \\
& C3 & 0.0 & 0.0 \\
& & 0.0 & 0.0 \\
\hline
\end{tabular}

A3 were mainly impacted by DO, with a positive correlation. The microbial communities of $\mathrm{B} 2$ and $\mathrm{B} 3$ were mainly impacted by FA because the FA concentration was higher than in reactor $\mathrm{A}$, and the microbial structure was greatly influenced. The microbial communities of $\mathrm{C} 2$ and $\mathrm{C} 3$ were distributed inverse to the vector of FA and DO, implying negative correlation. The microbial compositions reflected the FA and DO treatments in the experimental design.

With respect to the nitrification process and functional bacteria, DO was positive correlated with Nitrosomonas and Nitrobacter, whereas FA was negatively correlated with these genera. AOB activity and NOB activity were correlated with Nitrosomonas and Nitrobacter, respectively, suggesting that the AOB and NOB activity could indicate the abundance of functional bacteria.

\section{Discussion}

\section{Nitrite accumulation under high DO and high FA condition}

Ruiz et al. (2003) reported that DO value higher than $1.7 \mathrm{mg} / \mathrm{L}$ prevented nitrite accumulation. However, recent studies have observed high NAR at $4 \mathrm{mg} / \mathrm{L}$ DO in the treatment of high 

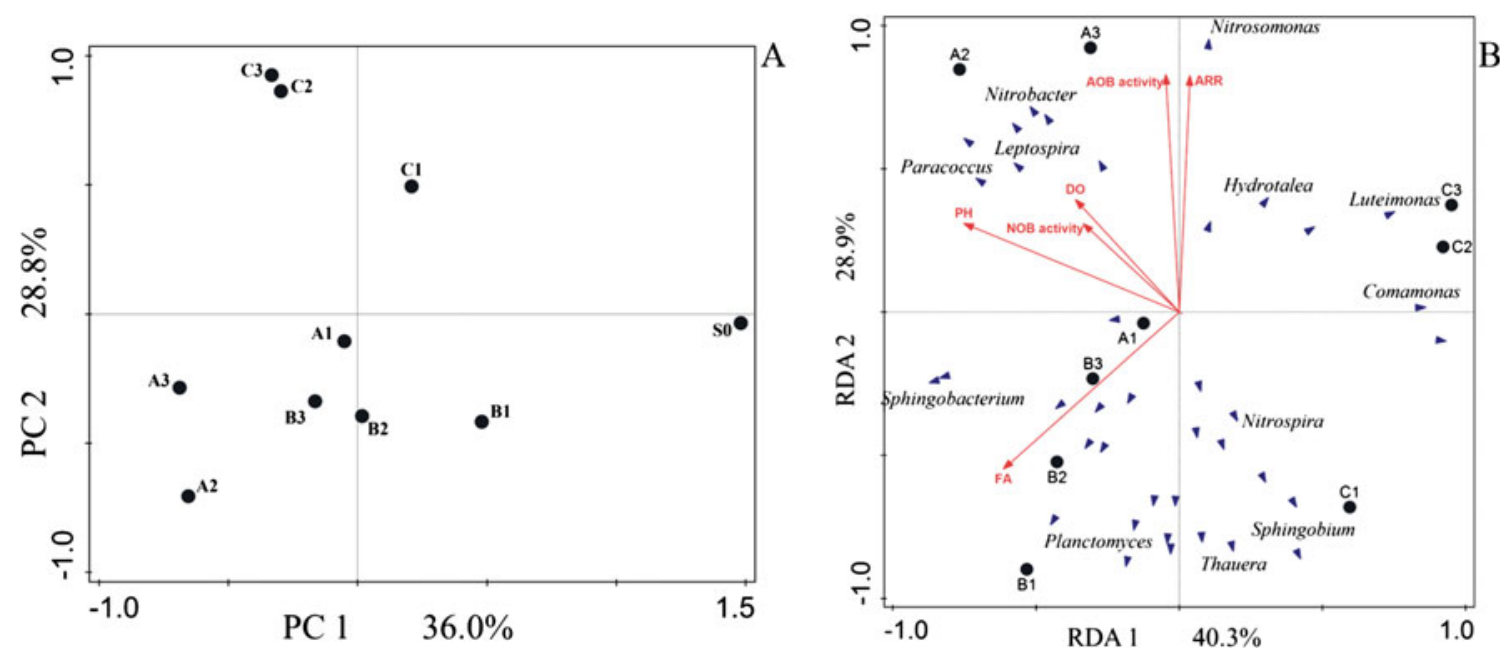

Fig. 4 Principal component analysis (PCA) based on genus data and redundancy analysis (RDA) based on the genus data as species variable and environmental parameters such as $\mathrm{DO}, \mathrm{pH}$, and etc. as environmental variables

ammonium wastewater (An et al. 2008; de Graaff et al. 2010; Park et al. 2014). Reactor A was designed to explore the mechanism of nitrite accumulation under high DO, the hypothesis of which is the relatively high inhibitive effect of FA on NOB.

For the high FA and high DO treatment (reactor A), the NAR was $95 \%$ at $7.14 \mathrm{mg} / \mathrm{L}$ FA in the initial 10 days. However, from day 15 to 30 , the FA concentration decreased to $4.05 \mathrm{mg} \mathrm{NH}_{3} / \mathrm{L}$, and nitrite failed to accumulate. Although the FA concentration was higher than the NOB inhibitory value of $0.1-1.0 \mathrm{mg} \mathrm{NH}_{3} / \mathrm{L}$ indicated by Anthonisen et al. (1976), nitrite did not accumulate. Chung et al. (2005) reported that DO increases NOB activity, and Villaverde et al. (2000) observed that NOB gradually adapt to FA inhibition. FA levels of $10-15 \mathrm{mgNH}_{3} / \mathrm{L}$ are needed to maintain highly efficient AOB and eliminate NOB for stable shortcut nitrification (Chung et al. 2005; Chen et al. 2010). In this study, from day 34 to 56 , NAR recovered to $84 \%$ when FA was $10.61 \pm 2.89 \mathrm{mg} \mathrm{NH}_{3} / \mathrm{L}$ (with a range of $7-16 \mathrm{mg} \mathrm{NH}_{3} / \mathrm{L}$ ) at $3.75 \pm 0.49 \mathrm{mg} / \mathrm{L}$ DO. Consistent with our findings, Park et al. (2014) suggested that $2.5-3.8 \mathrm{mg} / \mathrm{L} \mathrm{DO}$ and $15 \mathrm{mg} \mathrm{NH}_{3} / \mathrm{L} \mathrm{FA}$ are beneficial for nitrite accumulation. Our results indicated that FA should be increased to $10.61 \pm 2.89 \mathrm{mg} \mathrm{NH}_{3} / \mathrm{L}$ to achieve nitrite accumulation at $3.75 \pm 0.49 \mathrm{mg} / \mathrm{L}$ DO.

\section{Comparison of the performance of the three treatments}

The $\mathrm{NH}_{4}{ }^{+}$-N sludge load was 3.5-fold higher in the high FA and high DO treatment (reactor A) than in the other two treatments from day 34 to 56 , and the HRT was greatly reduced under high DO conditions. The $\mathrm{NH}_{4}{ }^{+}-\mathrm{N}$ load in reactor $\mathrm{A}$ was higher than the load of $0.04 \mathrm{~kg} \mathrm{~N} /(\mathrm{kg}$ MLSS day) reported by Deng et al. (2008) for the treatment of digested swine wastewater and $0.8 \mathrm{~kg} \mathrm{~N} /(\mathrm{kg}$ MLVSS day) reported by Gabarró et al. (2012) for the treatment of landfill leachate. Tokutomi et al. (2010) indicated that high DO could improve AOB tolerance to FA inhibition. DO of $5.0 \mathrm{mg} / \mathrm{L}$ and $\mathrm{pH}$ of 8.5 have been proposed as optimal to reduce the ammonium oxidizing time (Ciudad et al. 2007). Otawa et al. (2006) indicated that ammonium oxidation was the rate-limiting stage of nitrification and always required a long HRT and large aeration tank for the treatment of high ammonium wastewater. The AOB activity (Table 1) and AOB abundance confirmed that the high FA and high DO treatment greatly accelerated the ammonium oxidation process and maintained NAR at approximately $80 \%$, which could reduce the HRT or elevate the shortcut nitrification ability within the limited aeration tank.

Ruiz et al. (2003) proposed that DO is an effective controlling parameter for the stable maintenance of nitrite accumulation. In this study, under the low DO conditions in reactors B and C, NOB activity was lower and could not be detected from day 34 to 50 , and NOB were eliminated. At a low DO of $1.75 \pm 0.09 \mathrm{mg} / \mathrm{L}$, NAR was $94 \%$, higher than in the high FA and high DO treatment as well as the values of $65 \%$ reported by Ruiz et al. (2003) and $80 \%$ reported by Aslan et al. (2009). Although high NAR was achieved, AOB activity was also reduced. Liang et al. (2015) reported that a decrease in DO reduces both NOB and AOB activity. In this study, $\mathrm{AOB}$ activity and abundance were lower in the low DO treatment than the high DO treatment. The $\mathrm{NH}_{4}{ }^{+}-\mathrm{N}$ volumetric load was only one fourth of the value in the high FA and high DO treatment from day 34 to 56.

\section{Microbial shift driven by effects of DO and FA}

Ma et al. (2013) reported that a complete nitrification system has an NOB/AOB ratio of 230-500\%. The ratio of NOB/ $\mathrm{AOB}$ in the S0 sample was consistent with these values, 
confirming a complete nitrification system. In the different DO and FA treatments, the NOB/AOB ratio decreased sharply. In the low DO treatments, NOB was eliminated in the last two samples (B2, B3 and C2, C3), implying that low DO promoted NOB elimination, and no NOB activity could be detected during day 34 to 50 , further confirming NOB elimination (Table 1). With the high DO treatment in reactor A, although Nitrobacter accounted for only $1.1 \%$ of the population of Nitrosomonas in A3, nitrite oxidation occurred because NOB activity was enhanced by the high DO level, indicating that NOB cannot be eliminated under relatively high DO conditions, consistent with the results reported by Yadav et al. (2014).

According to Spearman correlation analysis, DO was positively correlated with AOB abundance $(p=0.045)$, AOB activity ( $p=0.05)$, NOB abundance $(p=0.034)$, and NOB activity $(p=0.00)$ and negatively correlated with NAR $(p=0.00)$. DO was also positively correlated with the $\mathrm{NH}_{4}{ }^{+}-\mathrm{N}$ volumetric load $(p=0.00)$ and sludge load $(p=0.00)$. However, FA was negatively correlated with NOB activity $(p=0.049)$ and the $\mathrm{NOB} / \mathrm{AOB}$ ratio $(p=0.00)$. DO enhanced the abundance and activity of $\mathrm{AOB}$ and NOB. However, FA reduced NOB activity and decreased the NOB/AOB ratio but did not eliminate NOB. Chung et al. (2005) indicated that DO exerts a greater impact on AOB and NOB than FA. In this study, in the high FA and high DO treatment, NOB activity was restrained by high FA inhibition, but AOB activity was enhanced by the high DO condition. A value of $84 \%$ NAR was achieved with a high $\mathrm{NH}_{4}{ }^{+}-\mathrm{N}$ load of $2.05 \pm 0.16 \mathrm{~kg}$ $\mathrm{N} /\left(\mathrm{m}^{3}\right.$ day), four times higher than under the low DO treatment. However, NOB was eliminated in reactor $\mathrm{C}$ under low FA and low DO conditions, with NAR of $94 \%$.

High FA and high DO treatment was efficient for nitrite accumulation. NAR of $84 \%$ was attained at $10.61 \pm 2.89 \mathrm{mg}$ $\mathrm{NH}_{3} / \mathrm{L}$ FA and $3.75 \pm 0.49 \mathrm{mg} / \mathrm{L}$ DO at SRT of $15-18$ days. Proteobacteria and Nitrosomonas was the dominant phylum and genus, respectively. Nitrosomonas was $54.57 \%$, and $\mathrm{NH}_{4}{ }^{+}-\mathrm{N}$ load was $2.05 \mathrm{~kg} \mathrm{~N} /\left(\mathrm{m}^{3}\right.$ day $)$. NOB activity was reduced by 3.56 -fold, and $\mathrm{NOB} / \mathrm{AOB}$ was decreased to $1.1 \%$. Low DO and low FA promoted NOB elimination with minimal $\mathrm{NO}_{3}{ }^{-}-\mathrm{N}$ production. But, $\mathrm{NH}_{4}{ }^{+}-\mathrm{N}$ load $(0.49 \mathrm{~kg}$ $\mathrm{N} /\left(\mathrm{m}^{3}\right.$ day $)$ )and AOB abundance $(22.61 \%)$ were much lower. High FA and low DO condition was not appropriate for highly efficient nitrite accumulation.

\footnotetext{
Acknowledgements This study was funded by non-profit Research Foundation for Agriculture (201303091), China Agriculture Research System (CARS-36), and the National Natural Science Foundation of China (No. 41501513).
}

Author contributions The manuscript was written through contributions of all authors. All authors have given approval to the final version of the manuscript.
Compliance with ethical standards This article does not contain any studies with human participants or animals performed by any of the authors.

Conflict of interest All authors declare no conflict of interest.

\section{References}

An Y, Yang F, Chua HC, Wong FS, Wu B (2008) The integration of methanogenesis with shortcut nitrification and denitrification in a combined UASB with MBR. Bioresour Technol 99:3714-3720. doi:10.1016/j.biortech.2007.07.020

Anthonisen AC, Loehr RC, Prakasam TB, Srinath EG (1976) Inhibition of nitrification by ammonia and nitrous acid. J Water Pollut Control Fed 48:835-852. doi:10.2307/25038971

Aslan S, Miller L, Dahab M (2009) Ammonium oxidation via nitrite accumulation under limited oxygen concentration in sequencing batch reactors. Bioresour Technol 100:659-64. doi:10.1016/j. biortech.2008.07.033

Chen J, Zheng P, Yu Y, Mahmood Q, Tang C (2010) Enrichment of high activity nitrifers to enhance partial nitrification process. Bioresour Technol 101:7293-7298. doi:10.1016/j.biortech.2010.04.080

Chuang HP, Ohashi A, Imachi H, Tandukar M, Harada H (2007) Effective partial nitrification to nitrite by down-flow hanging sponge reactor under limited oxygen condition. Water Res 41:295-302. doi: 10.1016/j.watres.2006.10.019

Chung J, Shim H, Lee YW, Bae W (2005) Comparison of influence of free ammonia and dissolved oxygen on nitrite accumulation between suspended and attached cells. Environ Technol 26:21-33. doi:10.1080/09593332608618587

Ciudad G, González R, Bornhardt C, Antileo C (2007) Modes of operation and $\mathrm{pH}$ control as enhancement factors for partial nitrification with oxygen transport limitation. Water Res 41:4621-4629. doi:10. 1016/j.watres.2007.06.036

de Graaff MS, Zeeman G, Temmink H, van Loosdrecht MCM, Buisman CJN (2010) Long term partial nitritation of anaerobically treated black water and the emission of nitrous oxide. Water Res 44: 2171-2178. doi:10.1016/j.watres.2009.12.039

Deng L, Zheng P, Chen Z, Mahmood Q (2008) Improvement in posttreatment of digested swine wastewater. Bioresour Technol 99: 3136-3145. doi:10.1016/j.biortech.2007.05.061

Gabarró J, Ganigué R, Gich F, Ruscalleda M, Balaguer MD, Colprim J (2012) Effect of temperature on AOB activity of a partial nitritation SBR treating landfill leachate with extremely high nitrogen concentration. Bioresour Technol 126:283-289. doi:10.1016/j.biortech. 2012.09.011

Guo CH, Stabnikov V, Ivanov V (2010) The removal of nitrogen and phosphorus from reject water of municipal wastewater treatment plant using ferric and nitrate bioreductions. Bioresour Technol 101:3992-3999. doi:10.1016/j.biortech.2010.01.039

Kim JH, Guo X, Park HS (2008) Comparison study of the effects of temperature and free ammonia concentration on nitrification and nitrite accumulation. Process Biochem 43:154-160. doi:10.1016/j. procbio.2007.11.005

Kozich JJ, Westcott SL, Baxter NT, Highlander SK, Schloss PD (2013) Development of a dual-index sequencing strategy and curation pipeline for analyzing amplicon sequence data on the miseq illumina sequencing platform. Appl Environ Microbiol 79:5112-5120. doi: 10.1128/AEM.01043-13

Krzywinski M, Schein J, Birol I, Connors J, Gascoyne R, Horsman D, Jones SJ, Marra MA (2009) Circos: An information aesthetic for 
comparative genomics. Genome Res 19:1639-1645. doi:10.1101/ gr.092759.109

Liang Y, Li D, Zhang X, Zeng H, Yang Z, Cui S, Zhang J (2015) Stability and nitrite-oxidizing bacteria community structure in different highrate CANON reactors. Bioresour Technol 175:189-194. doi:10. 1016/j.biortech.2014.10.080

Ma J, Wang Z, Yang Y, Mei X, Wu Z (2013) Correlating microbial community structure and composition with aeration intensity in submerged membrane bioreactors by 454 high-throughput pyrosequencing. Water Res 47:859-869. doi:10.1016/j.watres.2012.11.013

Otawa K, Asano R, Ohba Y, Sasaki T, Kawamura E, Koyama F, Nakamura S, Nakai Y (2006) Molecular analysis of ammoniaoxidizing bacteria community in intermittent aeration sequencing batch reactors used for animal wastewater treatment. Environ Microbiol 8:1985-1996. doi:10.1111/j.1462-2920.2006.01078.x

Park S, Chung J, Rittmann BE, Bae W (2014) Nitrite accumulation from simultaneous free-ammonia and free-nitrous-acid inhibition and oxygen limitation in a continuous-flow biofilm reactor. Biotechnol Bioeng 112:1-26. doi:10.1002/bit.25326

Peng Y, Zhu G (2006) Biological nitrogen removal with nitrification and denitrification via nitrite pathway. Appl Microbiol Biotechnol 73: 15-26. doi:10.1007/s00253-006-0534-Z

Persson F, Sultana R, Suarez M, Hermansson M, Plaza E, Wilén B (2014) Structure and composition of biofilm communities in a moving bed biofilm reactor for nitritation - anammox at low temperatures. Bioresour Technol 154:267-273. doi:10.1016/j.biortech.2013.12. 062

Regmi P, Miller MW, Holgate B, Bunce R, Park H, Chandran K, Wett B, Murthy S, Bott CB (2014) Control of aeration, aerobic SRT and COD input for mainstream nitritation/denitritation. Water Res 57: 162-171. doi:10.1016/j.watres.2014.03.035

Ruiz G, Jeison D, Chamy R (2003) Nitrification with high nitrite accumulation for the treatment of wastewater with high ammonia concentration. Water Res 37:1371-1377. doi:10.1016/S0043-1354(02) 00475-X

Tokutomi T, Shibayama C, Soda S, Ike M (2010) A novel control method for nitritation: The domination of ammonia-oxidizing bacteria by high concentrations of inorganic carbon in an airlift-fluidized bed reactor. Water Res 44:4195-4203. doi:10.1016/j.watres.2010.05. 021

Vadivelu VM, Keller J, Yuan Z (2007) Free ammonia and free nitrous acid inhibition on the anabolic and catabolic processes of
Nitrosomonas and Nitrobacter. Water Sci Technol 56:89-97. doi: 10.2166/wst.2007.612

Villaverde S, Fdz-Polanco F, García PA (2000) Nitrifying biofilm acclimation to free ammonia in submerged biofilters. Start-up influence. Water Res 34:602-610. doi:10.1016/S0043-1354(99)00175-X

Waheed H, Hashmi I, Naveed AK, Khan SJ (2013) Molecular detection of microbial community in a nitrifying-denitrifying activated sludge system. Int Biodeterior Biodegrad 85:527-532. doi:10.1016/j.ibiod. 2013.05.009

Wang Q, Garrity GM, Tiedje JM, Cole JR (2007) Naïve Bayesian classifier for rapid assignment of rRNA sequences into the new bacterial taxonomy. Appl Environ Microbiol 73:5261-5267. doi:10.1128/ AEM.00062-07

Wang Q, Ye L, Jiang G, Yuan Z (2013) A free nitrous acid (FNA)-based technology for reducing sludge production. Water Res 47:36633672. doi:10.1016/j.watres.2013.04.016

Wyffels S, Van Hulle SWH, Boeckx P, Volcke EIP, Van Cleemput O, Vanrolleghem PA, Verstraete W (2004) Modeling and simulation of oxygen-limited partial nitritation in a membrane-assisted bioreactor (MBR). Biotechnol Bioeng 86:531-542. doi:10.1002/bit.20008

Yadav TC, Khardenavis AA, Kapley A (2014) Shifts in microbial community in response to dissolved oxygen levels in activated sludge. Bioresour Technol 165:257-264. doi:10.1016/j.biortech.2014.03. 007

Zhang J, Cai X, Qi L, Shao C, Lin Y, Zhang J, Zhang Y, Shen P, Wei Y (2015) Effects of aeration strategy on the evolution of dissolved organic matter (DOM) and microbial community structure during sludge bio-drying. Appl Microbiol Biotechnol. doi:10.1007/s00253015-6640-z

Zhang M, Lawlor PG, Wu G, Lynch B, Zhan X (2011) Partial nitrification and nutrient removal in intermittently aerated sequencing batch reactors treating separated digestate liquid after anaerobic digestion of pig manure. Bioprocess Biosyst Eng 34:1049-1056. doi:10.1007/ s00449-011-0556-5

Zhang SJ, Peng YZ, Wang SY, Zheng SW, Guo J (2007) Organic matter and concentrated nitrogen removal by shortcut nitrification and denitrification from mature municipal landfill leachate. J Environ Sci 19:647-651. doi:10.1016/S1001-0742(07)60108-9

Zhang T, Shao M-F, Ye L (2012) 454 Pyrosequencing reveals bacterial diversity of activated sludge from 14 sewage treatment plants. ISME J 6:1137-1147. doi:10.1038/ismej.2011.188 